\title{
Decline in hepatitis B infection in sickle cell anaemia and $\beta$ thalassaemia major
}

\author{
I Al-Fawaz, S Ramia
}

\begin{abstract}
Seventy five Saudi children, 55 with sickle cell anaemia and 20 with $\beta$ thalassaemia major, who were negative for all hepatitis $B$ virus (HBV) markers five years ago were recently investigated for exposure to $\mathrm{HBV}$ and hepatitis $C$ virus (HCV) infection. Of the 55 patients with sickle cell anaemia and 20 with $\beta$ thalassaemia major, 20 and five patients respectively had been vaccinated against HBV earlier and all of them still had protective antibody (anti-HBs 42-96 IU) 3-5 years after vaccination and there was no vaccine failure. Among the nonvaccinated children the exposure rates to HBV were $14 \cdot 3 \%$ among those with sickle cell anaemia and $26.7 \%$ among those with $\beta$ thalassaemia and this was not statistically significant when compared with the exposure rate to $\mathrm{HBV}$ among the general paediatric population $(20 \cdot 1 \%)$. Anti-HCV positivity among those with $\beta$ thalassaemia major and sickle cell anaemia was $70 \%$ and $18 \cdot 2 \%$, respectively, and this was significantly higher than anti-HCV positivity among the control group (0.8\%). Anti-HCV positivity was directly related to the amount of blood transfused and to the duration of transfusion. The results of the study show that although the exposure rates to $\mathrm{HBV}$ among patients with sickle cell anaemia and $\beta$ thalassaemia major were not significantly different than that among the general paediatric population, infection with HBV still takes place among non-vaccinated patients despite strict precautionary measures taken. Hence early vaccination against $\mathrm{HBV}$ would probably be the only effective way of controlling $\mathrm{HBV}$ infection. For $\mathrm{HCV}$ infection, and because a vaccine against $H C V$ is still not available, preventive measures such as blood screening for anti-HCV before transfusion and stringent infection control measures are crucial steps to be implemented for the control of spread of $\mathrm{HCV}$ among these groups of patients. (Arch Dis Child 1993; 69: 594-596)
\end{abstract}

College of Medicine, King Saud University, 11461, Saudi Arabia, Department of Paediatrics

I Al-Fawaz

Department of Pathology $S$ Ramia

Correspondence to: Dr Al-Fawaz.

Accepted 23 July 1993

Hepatitis $\mathrm{C}$ virus $(\mathrm{HCV})^{1}$ was recently identified as the major causative agent of transfusion non-A, non-B hepatitis ${ }^{2}$ and diagnosis of infection has been made possible by the development of an anti-HCV assay. ${ }^{4}$ Groups at high risk of infection with $\mathrm{HCV}$ are those who receive multiple blood transfusions such as haemophiliacs, ${ }^{5}$ patients on haemodialysis, ${ }^{67}$ and those with thalassaemia. ${ }^{8}$
In addition to $\mathrm{HCV}$, multitransfused patients are also at a high risk of acquiring hepatitis $B$ virus (HBV) infection. ${ }^{9}$ Previously we have shown that multitransfused Saudi patients with sickle cell anaemia and thalassaemia have a high exposure rate to HBV. ${ }^{11}$ Because of this, strict measures were implemented at our hospital to control the spread of $\mathrm{HBV}$ infection. These included improved infection control, vaccination against $\mathrm{HBV}$, and using third generation techniques for screening for hepatitis B surface antigen (HBsAg). This report is concerned with the prevalence of HBV infection in the above mentioned two groups of Saudi patients five years after implementation of the control measures and also with the prevalence of anti$\mathrm{HCV}$ using the recently available screening and confirmatory second generation enzyme immunoassay techniques.

\section{Patients and methods}

PATIENTS STUDIED

Fifty five Saudi children with sickle cell anaemia ( 30 boys, 25 girls; age range $2 \cdot 5-14$ years) and 20 Saudi children with $\beta$ thalassaemia major (11 boys, nine girls; age range 1-14 years) who attended the haematology clinic at King Khalid University Hospital, Riyadh, were included in this study. The diagnosis was confirmed by haemoglobin electrophoresis on cellulose acetate at $\mathrm{pH} 8.6$ and citrate agar at $\mathrm{pH} 6.0$. Adult and fetal haemoglobins were estimated by the elution method and alkaline denaturation respectively as described earlier. ${ }^{12}$ Routine screening for $\mathrm{HBsAg}$ and antibody to $\mathrm{HBsAg}$ (anti-HBsAg) were done on each patient on the initial visit to the clinic. No screening for antibody to $\mathrm{HCV}$ (anti-HCV) was performed as the test was not available then. Among the 55 children with sickle cell anaemia and the 20 children with $\beta$ thalassaemia major, $20(36.4 \%)$ and five $(25 \%)$, respectively, were already vaccinated (three doses) against HBV. Those who were vaccinated were the only ones whose parents accepted the theoretical risk from a plasma derived vaccine. Genetically derived HBV vaccine became available only recently at our hospital.

\section{CONTROL GROUP}

The control group consisted of 120 Saudi children (60 boys, 52 girls; age range 1-12 years) who were investigated in another research project regarding the age specific prevalence of $\mathrm{HBV}$ markers among Saudi 
Table 1 HBV markers and antibody to HCV (anti-HCV) in multitransfused Saudi patients with sickle cell anaemia and $\beta$ thalassaemia major

\begin{tabular}{llllll}
\hline \multicolumn{5}{l}{$N o(\%) H B V$ markers positive } \\
\cline { 2 - 6 } & $H B s A g$ & $\begin{array}{l}\text { Anti-HBc } \\
\text { alone }\end{array}$ & $\begin{array}{l}\text { Anti-HBc and } \\
\text { anti-HBs }\end{array}$ & $\begin{array}{l}\text { Anti-HBs } \\
\text { alone }\end{array}$ & $\begin{array}{l}\text { Anti-HCV } \\
\text { positive }\end{array}$ \\
\hline $\begin{array}{l}\text { Controls }(\mathrm{n}=120) \\
\begin{array}{l}\text { Sickle cell anaemia } \\
(\mathrm{n}=55)\end{array}\end{array}$ & $7(5 \cdot 8)$ & $1(0 \cdot 8)$ & $14(11 \cdot 7)$ & $3(2 \cdot 5)$ & $1(0 \cdot 8)$ \\
$\beta \begin{array}{l}\text { Thalassaemia major } \\
(\mathrm{n}=20)\end{array}$ & 0 & 0 & $5(14 \cdot 3)^{\star}$ & $20(36 \cdot 4) \dagger$ & $10(18 \cdot 2)$ \\
& 0 & 0 & $4(26 \cdot 7)^{\star}$ & $5(25 \cdot 0) \dagger$ & $14(70 \cdot 0)$
\end{tabular}

*These patients had no history of vaccination against HBV.

†These patients were vaccinated (three doses) against HBV.

children. The sampling strategy of these children has already been detailed. ${ }^{13}$ The control group were not vaccinated against HBV.

\section{SEROLOGY STUDIES}

All sera were tested for HBV markers (HBsAg; total antibody to HBsAg (anti-HBs); total antibody to hepatitis $\mathrm{B}$ core antigen ( $\mathrm{HBcAg}$ ) (anti-HBc), and to hepatitis $\mathrm{B} e$ antigen $(\mathrm{HBeAg})$ ) by the enzyme linked immunosorbent assay (ELISA) from Organon Teknika $\mathrm{NV}$, Belgium and for anti-HCV by ELISA from Abbott Laboratories, North Chicago, Illinois, USA. All anti-HCV positive samples were confirmed by the Abbott HCV enzyme immunoassay supplemental assay. Specimens from children who were vaccinated against HBV were tested by ELISA from Organon Teknika and an anti-HBs titre of $\geqslant 10 \mathrm{mIU}$ was considered positive. The procedures followed in all assays were as stated by the manufacturer.

SERUM ALANINE AMINOTRANSFERASE

Alanine aminotransferase activities were considered abnormal if they were at least 1.5 times the normal value $(0-56 \mathrm{IU})$.

\section{STATISTICAL ANALYSIS}

Fisher's exact test and $\chi^{2}$ test were used in the comparison of proportions. Mean values were compared using Student's $t$ test.

\section{Results}

Prevalence of $\mathrm{HBV}$ markers and anti-HCV among multitransfused Saudi patients with sickle cell anaemia and $\beta$ thalassaemia major is shown in table 1 . Seven $(5 \cdot 8 \%)$ of the controls were $\mathrm{HBsAg}$ positive and none of the patients was a carrier. Among the 35 patients with sickle cell anaemia and who were not vaccinated against $\mathrm{HBV}$ five $(14 \cdot 3 \%)$ were exposed

Table 2 Comparison of patients with sickle cell anaemia and $\beta$ thalassaemia major who were positive or negative for anti-HCV

\begin{tabular}{|c|c|c|c|c|c|c|}
\hline & \multicolumn{3}{|c|}{ Sickle cell anaemia } & \multicolumn{3}{|c|}{ B Thalassaemia major } \\
\hline & $\begin{array}{l}\text { Positive } \\
(n=10)\end{array}$ & $\begin{array}{l}\text { Negative } \\
(n=45)\end{array}$ & p Value & $\begin{array}{l}\text { Positive } \\
(n=14)\end{array}$ & $\begin{array}{l}\text { Negative } \\
(n=5)\end{array}$ & p Value \\
\hline Mean age (years) & $10 \cdot 1$ & $11 \cdot 0$ & $>0.05$ & $9 \cdot 2$ & $4 \cdot 0$ & $<0.03$ \\
\hline \multicolumn{7}{|c|}{ Amount of blood transfused/year (units) } \\
\hline$\leqslant 5$ & 1 & 40 & \multirow{2}{*}{$<2 \times 10^{-6}$} & 0 & 4 & \multirow{2}{*}{$<0.003$} \\
\hline$>6$ & 9 & 5 & & 14 & 2 & \\
\hline
\end{tabular}

to $\mathrm{HBV}$ (anti-HBc and anti-HBs positive) compared with 25 patients (14 anti-HBc and anti-HBs positive, one anti-HBc positive, three anti-HBs positive, and seven $\mathrm{HBsAg}$ positive) among the control group; this was not statistically significant $(p=0.535)$. Among the 15 patients with $\beta$ thalassaemia major who were not vaccinated against HBV four $(26 \cdot 7 \%)$ had evidence of exposure to $\mathrm{HBV}$ (anti-HBc and anti-HBs), which also was not statistically significant compared to the exposure rate to $\mathrm{HBV}$ $(20 \cdot 8 \%)$ among the control group $(p=0 \cdot 815)$. There was no vaccine failure against HBV among the 25 patients vaccinated and the antiHBs titre range was $42-96$ IU 3-5 years after vaccination.

Anti-HCV positivity among patients with $\beta$ thalassaemia major was $70 \%$ compared with $18 \cdot 2 \%$ among patients with sickle cell anaemia and $0 \cdot 8 \%$ among the control group (table 1 ). Anti-HCV was significantly higher in those with $\beta$ thalassaemia major than in those with sickle cell anaemia $\left(p<7 \times 10^{-5}\right)$ and among the control group $\left(\mathrm{p}<10^{-8}\right)$. Furthermore, antiHCV positivity among the patients with sickle cell anaemia was significantly higher than that among the control group $\left(p<4 \times 10^{-5}\right)$. Among patients with sickle cell anaemia as well as among those with $\beta$ thalassaemia major antiHCV positivity was directly related to the amount of blood transfused (table 2). In addition to the amount of blood transfused, the duration of transfusion, particularly among the thalassaemics, influenced the rate of anti-HCV positivity (table 2 ).

\section{Discussion}

Our earlier data from the Riyadh area showed an exposure rate to $\mathrm{HBV}$ of $30.8 \%$ in the general paediatric population compared with $45.3 \%$ and $79.4 \%$ in sickle cell anaemia and $\beta$ thalassaemia major patients, respectively. ${ }^{11}$ The results of this study show clearly that the exposure rate to HBV has been reduced drastically in the same groups of patients who were not vaccinated against $\mathrm{HBV}$. This reduction is most probably due to the use of the most sensitive third generation techniques for screening $\mathrm{HBsAg}$ in all blood donors during the past five years in addition to the strict precautionary measures applied at our hospital against spread of HBV infection. However, although the exposure rate among our patients was not different from that among the general paediatric population, infection with $\mathrm{HBV}$ still takes place among unvaccinated patients with thalassaemia and sickle cell anaemia. This infection is most probably due to frequent exposure to blood in these patients but intrafamilial spread cannot be ruled out. ${ }^{14}$ In all of our exposed patients, the infection was subclinical. The finding of no vaccine failure against $\mathrm{HBV}$ among our 25 vaccinated patients underscores the importance of vaccinating all patients with thalassaemia and sickle cell anaemia who have not been exposed to HBV. Early vaccination of these patients would probably be the only effective way of controlling $\mathrm{HBV}$ infection as $\mathrm{HBsAg}$ free blood cannot completely safeguard against HBV 
infection. ${ }^{1516}$ Vaccination against $\mathrm{HBV}$ is now a part of the Expanded Programme of Immunisation in Saudi Arabia. ${ }^{17}$

In contrast to the situation with HBV our patients, and particularly those with $\beta$ thalassaemia major, are highly exposed to $\mathrm{HCV}$ $(70 \%)$. This is much higher than what has been reported earlier ${ }^{5}$ where the first generation enzyme immunoassay test for anti-HCV was used. Hence, earlier data on anti-HCV have to be interpreted with caution in the light of relative insensitivity ${ }^{18}{ }^{19}$ and specificity ${ }^{2021}$ of this first generation immunoassay. A similarly high exposure rate to $\mathrm{HCV}$ infection has recently been reported among Saudi patients on haemodialysis using a second generation immunoassay (S Huraib et al, personal communication). Whether some of these second generation assay results are false positive still awaits the development of more reliable confirmatory tests. The finding that only $15 \%$ of our anti-HCV positive patients had raised alanine aminotransferase activities and none of them was anti-HBc positive indicates that these surrogate markers are not reliable for predicting HCV infection and is in agreement with our earlier observation ${ }^{22}$ and those of others. ${ }^{23}$ Higher frequency hospital admission and hence blood transfusion in thalassaemics compared with patients with sickle cell anaemia may explain the difference in exposure rate to $\mathrm{HCV}$ found among the two groups.

In conclusion, it seems therefore that until a vaccine against $\mathrm{HCV}$ becomes available, preventive measures such as blood screening for anti-HCV before transfusion and stringent infection control measures are crucial for the control of spread of $\mathrm{HCV}$ among these categories of patients. This is particularly important as recent evidence indicates that $\mathrm{HCV}$ does not illicit long term immunity and reinfection with a homologous strain is possible. ${ }^{24}$

1 Choo QL, Kuo G, Weiner AJ, Overby LR, Bradley DW, Houghton $M$. Isolation of a cDNA clone derived from a blood-borne non-A, non-B viral hepatitis genome. Science 1989; 244: 359-62.

2 Hopf U, Moller B, Kuther D, et al. Long-term follow-up of post-transfusion and sporadic chronic hepatitis non-A, non-B and frequency of circulating antibodies to hepatinon-B and frequency of circulating antibodies
3 Wang JT, Wang TH, Liu JT, Shen JC, Sung JL, Chen DS. Hepatitis $C$ virus in a prospective study of post-
transfusion non-A, non-B hepatitis in Taiwan. $\mathcal{F}$ Med Virol 1990; 32: 83-6.

4 Kuo G, Choo QL, Alter HJ, et al. An assay for circulating antibodies to a major etiologic virus of human non-A, antibodies to a major etiologic virus of hun

5 Bahakim H, Bakir TMF, Arif M, Ramia S. Hepatitis C virus antibodies in high risk Saudi groups. Vox Sang 1991; 60: $162-4$

6 Oguchi H, Terashima M, Tokunaga S, et al. Prevalence of anti-HCV in patients on long-term hemodialysis. Nippon finzo Gakkai Shi 1990; 32: 313-7.

7 Zeldis JB, Depner TA, Kuramoto IK, Gish RG, Holland PV. The prevalence of hepatitis $C$ virus antibodies among hemodialysis patients. Ann Intern Med 1990; 112: 958-60.

8 Wonke B, Hoffbrand AV, Brown D, Dusheiko G. Antibody to hepatitis $C$ virus in multiple transfused patients with thalassemia major. 7 Clin Pathol 1990; 43: 638-40.

9 Kaime WN. Hepatitis B surface antigen in Nigerian children with sickle cell anaemia. $\mathcal{F}$ Trop Pediatr 1983; 29: 55-8.

10 Miele-Vergani G, Vergani D, White Y, et al. Hepatitis B virus infection in thalassaemia major treated in London and Athens. BMF 1984; 288: 1804-7.

11 El-Hazmi MAF, Ramia S. Frequencies of hepatitis B, delta and human immune deficiency virus markers in multitransfused Saudi patients with thalassemia and sickle cell disease. F Trop Pediatr 1989; 92: 1-5.

12 El-Hazmi MAF. Hemoglobin disorders: a pattern for thalassemia and hemoglobinopathies in Arabia. Acta Hematol (Basel) 1982; 68: 43-51.

13 Al-Faleh FZ, Ayoola EA, Aruf M, et al. Seroepidemiology of hepatitis B virus infection in Saudi Arabian children: a hepatitis B virus infection in Saudi Arabian children: a baseline survey for mass

14 Ramia S. Intrafamilial clustering of hepatitis B virus (HBV) infection: study of 10 Saudi families. Ann Trop Med Parasitol 1990; 84: 623-8.

15 Papaevangelou G, Roumeliotou-Karayannis A, Tassopoulous N, Stathopoulou P. Diagnostic value of anti-HBcIgM in high prevalence areas. $\mathcal{F}$ Med Virol 1984; 13: 393-9.

16 Ramia S, Bakir TMF, Hossain A, El-Hazmi MAF. HBsAg and anti-HBsAg detection. Results of comparative testing in HBV endemic area. Saudi Medical fournal 1987; 8: in HB-3.

17 Al-Faleh FZ, Ayoola EA, Al-Jeffry M, et al. Integration of hepatitis $B$ vaccine into the expanded programme of immunization: the Saudi Arabian experience. Annals Saudi Medicine 1993; 13: 231-6.

18 Weiner AJ, Kuo G, Bradley DE, et al. Detection of hepatitis $C$ viral sequences in non-A, non-B hepatitis. Lancet 1990; 335: 1-3.

19 Okamoto H, Okada S, Sugiyama Y, et al. Detection of hepatitis $C$ virus RNA by a two-stage polymerase chain reaction with two pairs of primers deduced from the 5 ' non-coding region. Ipn $\mathcal{F}$ Exp Med 1990; 60: 215-22.

non-coding region. Fpn f Exp Med 1990; 60: $215-22$.
Pascual M, Perrin L, Giostra E, Schifferli JA. Hepatitis C virus in patients with cryoglobulinemia type II. F Infect Dis 1990; 160: 567-9.

21 Boudart D, Lucas JC, Muller JY, et al. False-positive hepatitis $C$ virus antibody tests in paraproteinaemia. Lancet 1990; 336: 63.

22 Ayoola EA, Huraib S, Arif M, et al. Prevalence and significance of antibodies to hepatitis $\mathrm{C}$ virus among Saud hemodialysis patients. $\mathcal{F}$ Med Virol 1991; 35: 155-9.

23 Willems M, Tong G, Moshage H, et al. Surrogate markers are not useful for identification of HCV carriers in chronic hemodialysis patients. $\mathcal{F}$ Med Virol 1991; 35: 303-6.

24 Farci $P$, Alter HJ, Govindarjan S, et al. Lack of protective immunity against reinfection with hepatitis $C$ virus. Science 1992; 258: 135-40. 